\title{
SAVINGS AND ECONOMIC GROWTH IN SOUTH AfRICA: A MULTIVARIATE ANALYSIS
}

\author{
Kafayat Amusa* \\ University of South Africa \\ amusako@unisa.ac.za
}

Received: December 2012

Accepted: June 2013

\begin{abstract}
Growth theories highlight the importance of domestic savings for Economic growth. The savings and growth literature points generally to a positive growth effect of domestic savings. For a country like South Africa, where the level of domestic saving is low, the question of the role of savings in economic growth becomes critical. An understanding of the contribution of the different forms of savings in an economy to its economic growth is important, especially to be able to make the proper policy addresses. This paper applies cointegration analysis within a multivariate framework to establish the effect of household, government and corporate savings on economic growth in South Africa. The result indicates that corporate saving has a significant positive relationship to growth in both the long and short run, while household and government saving have no significant impact on growth. There is need for policies that increase the level of domestic savings and also a need to address government policies that impact on both public and household savings rate
\end{abstract}

Keywords

Savings; Economic growth; Bounds; Cointegration; South Africa.

*Mr K Amusa is a lecturer in the Department of Economics, University of South Africa, South Africa. 


\section{INTRODUCTION}

Given the importance of savings in the economic growth process, this relationship has been examined and continues to be examined in different contexts by researchers. Solow (1956) hypothesised that by increasing savings and therefore by extension investment, faster growth is achievable. This hypothesis was further complemented by the proposal that nations with low investment stock but high savings would experience a faster growth pace than those with high investment and low savings. The hypothesis put forward by Solow gained further ground when in their seminal work McKinnon and Shaw (1973) advocated financial liberalisation based on their findings that promoting investments through increased savings was the way to achieving development. As a result of years of numerous studies that have built on the early works of Solow (1956) and McKinnon and Shaw (1973) and others, the general consensus reached in the literature is that domestic savings are essential to attaining a sustained level of economic growth and plays a crucial role in promoting strong and sustained economic growth if channelled towards profitable, sound and appropriate investments opportunities (Amusa \& Moyo, 2013).

South Africa's savings rate has been on the decline over the last few decades, with the savings GDP ratio sitting around the $14 \%$ mark from 2005 onwards, the lowest in many years. The impact of low savings has translated into declining levels of both public and private investments, thus affecting the economic growth of a growing or emerging economy such as South Africa's. In light of this, the South African authority has taken steps to boost domestic savings, including the promotion of an environment that fosters a high savings culture. Given government's commitment to raising savings levels, it is important to have an understanding of the importance of savings in South Africa's economic growth. South Africa has arguably the most developed economy on the continent, with one of the best financial systems in Africa and therefore this study can provide insight into the relevance of savings in boosting growth. While a number of studies have analysed the savings-growth hypothesis, the use of aggregate data clouds important aspects of distinguishing between different sources of domestic savings, that is household, corporate and government savings. Looking at each form of savings ensures that rather than having an encompassing policy to improve savings, knowledge of how each particular source contributes to savings and therefore economic growth would allow for appropriate policy recommendations to be made.

Despite the policy importance of determining the significance of savings for the growth process, and quantifying their effects, there is still a paucity of research analysing the relationship between the different sources of savings and economic growth in developing countries. In the studies that do exist, the focus has been on aggregate savings rates - see for example Salz (1999), Odhiambo (2009) and Romm (2003). This leaves a gap in the literature that needs to be filled in terms of understanding the effect of different saving modalities on economic growth. While there are a few case studies specific to South Africa, the principal focus has been on analysing the relationship between savings and growth from the aggregate savings point of view (Odhiambo, 2009; Romm, 2003).

This paper differs from Romm (2003) in two important aspects. This study differs from Romm (2003) in two aspects. The problem with this approach is that it does not enhance the ability to make proper policy decisions which are tailored specifically to improving the levels of the different sources of savings. To address this issue literature on savings-growth nexus is drawn upon, cognisance is taken of the different savings sources, and the savings and growth relationship in South Africa is examined using data from 1953 to 2008. Second, while other 
studies make use of the popular Engle-Granger causality approach. This study employs an Autoregressive Distributed Lag (ARDL) bounds-testing approach to cointegration to determine both the long-run and short-run effects of the different modalities of savings on economic growth. In addition, the period of study is updated from 1992 (in the Romm study) to 2008.

The rest of the paper is structured as follows. Section 2 provides an overview of savings and economic growth in South Africa and is followed by a review of literature in section 3. Section 4 explains the econometric methodology followed in the study and presents the model and outlines relevant data issues. Empirical results are presented and main findings are discussed in Section 5 , while section 6 summarises and concludes.

\section{BACKGROUND TO SAVINGS AND ECONOMIC GROWTH IN SOUTH AFRICA}

\subsection{Savings trends in South Africa}

It is widely acknowledged that the savings rate in South Africa is relatively low. The low and continued decline in the national savings rate is concerning, since it increases resource constraint pressures and impedes investments that could potentially enhance growth (Aron \& Muellbauer, 2000). Resource constraints foster an environment of external borrowing, which increases the country's dependence on foreign resources to finance investment and leaves behind a legacy of heavy debt repayment that is passed on to citizens. As indicated by Aron and Muellbauer (2000), savings-wise, when compared to other emerging market economies, South Africa ranks poorly and the low domestic saving rates may hinder investment-driven growth in the medium term in South Africa.

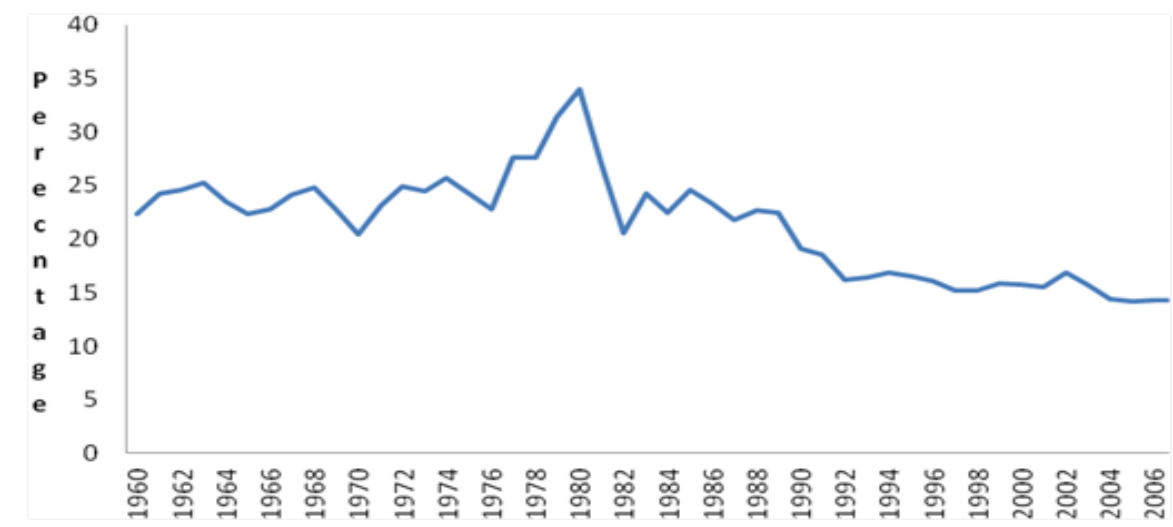

FIGURE 1: Ratio of Gross National Savings to GDP (1960-2007)

Source: South Africa Reserve Bank (SARB) online database (2011)

South Africa's savings trend can be divided into two distinct periods: the apartheid era and the post-apartheid era. From the late 1940s till the late 1990s there was a steady increase in the savings ratio. A possible reason for this high savings ratio is the isolation of the country from the rest of the world as protests against apartheid grew in strength. This forced South Africa to rely on its own savings to finance its investment demand. The opening up of the South African economy to the rest of the world in the post-apartheid period saw a steady decline in the 
national savings rate. There was an increase in foreign investment into the domestic economy and large-scale borrowings to finance much of the country's investment. This therefore meant that domestic savings was not the sole source of resources. Total savings in South Africa is divided into government (public) on one hand and household and corporate (private) savings on the other hand. Throughout the years the different components of national savings have contributed differing amounts to total savings.

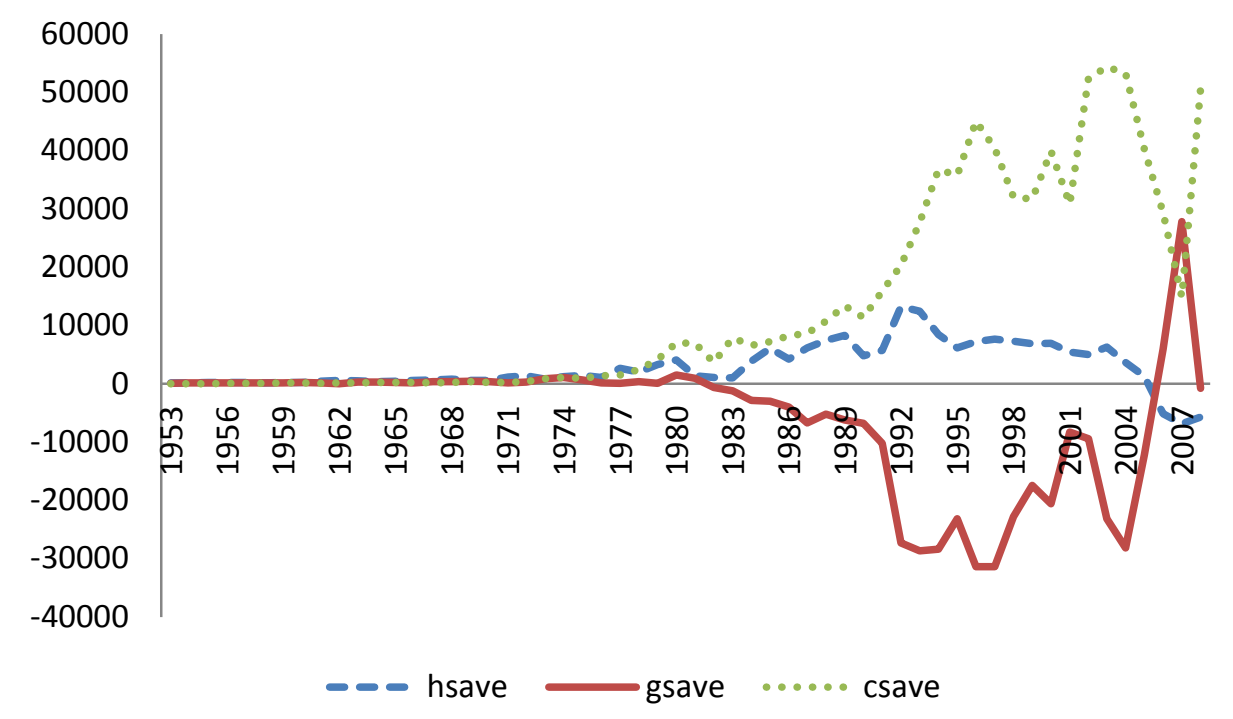

FIGURE 2: Share of Household, Government and Corporate savings in total savings (R millions)

Source: South Africa Reserve Bank (SARB) online database (2011)

Up to the 1970s all components of domestic savings contributed almost the same to total savings. However from the late 1970's corporate savings became the biggest source of domestic savings followed by household savings, while the contribution of government declined, reaching its lowest levels in the 1980's, the public sector became a net dissaver a pattern that continued through to 1993. The major contributor to the declining domestic saving rate is the decline in government savings, a decline attributed to an increase in government consumption expenditure. According to the SARB (1993), around 1996, government savings started to pick up, a trend that reflected government's effort to maintain fiscal discipline. By the mid-2000s government savings began contributing positively. Private savings, especially household savings, have also been on the decline from the mid-1980s. This decline is attributed to the decrease in corporate savings and the continued low level of household savings. Although corporate savings declined in some years, they remain the highest contributor to total savings.

In terms of the performance of the three forms of saving with respect to gross domestic product (GDP), we observe the same trend. FIGURE 3 shows household, corporate and government savings as a percentage of GDP (1953-2008). 


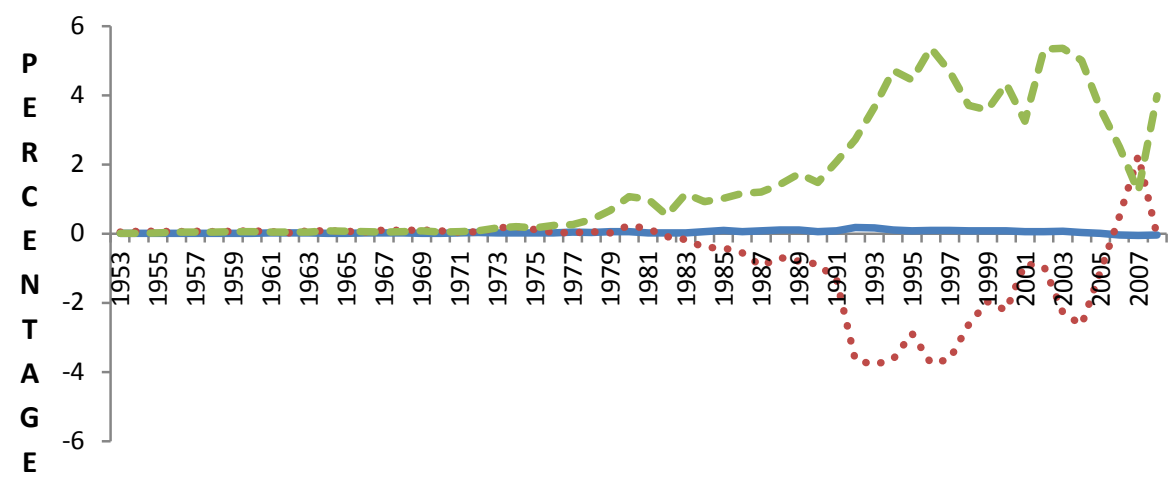

$\longrightarrow \mathrm{HS} \cdots \mathrm{GS}--\mathrm{CS}$

\section{FIGURE 3: Ratio of Government, Household and Corporate Savings to GDP}

\section{Source: South African Reserve Bank (SARB) Online Database (2011)}

Corporate savings are the mainstay of domestic saving in South Africa, given that the gross corporate saving GDP ratio has been greater than the combined savings of household and government since 1979 (SARB, 1993). Between 1979 and 1984 the corporate sector's saving ratio rose temporarily, mainly because of the increase in the gross operating surplus of the goldmining industry, due to the boom in gold prices (Prinsloo, 2000). Throughout the 1970s, government saving averaged about $5.5 \%$ of GDP. In comparison, household saving has been dismal, with the ratio of household saving to GDP declining from an average of $9.1 \%$ between 1960 and 1972 to $4.2 \%$ from 1990 to 1999. Between 1988 and 1990, household saving declined due to a high propensity to consume and picked up slightly due to more restrained consumption behaviour.

The overall downward trend in household savings has been a global phenomenon, with many industrialised nations experiencing waning personal savings. For South Africa the decline was attributed to a decline in the real income growth of households. Other factors that have been identified as contributing to the declining trend of household savings include changes in average income levels, the distribution of income amongst households, government savings, corporate savings and the ability of individuals to 'pierce the corporate veil', unemployment and financial deregulation (Prinsloo, 2000). While each of these different savings components have experienced short periods of increases, it is clear that from the early 1990 s the general trend has been downwards - thus painting a negative savings picture for the South African economy post1994 (see FIGURE 2 for the share of all three forms of savings in total savings).

\subsection{Economic growth}

South Africa's macro-economic policy conduct has also come under criticism. In the 1950s and 1960 s the policy objectives showed that economic growth was the dominating factor in determining fiscal policy. In recent years, the policy has shifted towards controlling inflation and maintaining a surplus on the current account. The lack of coordination between strategy and macro-economic policy, especially when macro policy is conducted without an agenda, has adverse consequences. In recent times, the country's macro policy has been more a reaction to 
economic shocks, resulting in many of these policies conflicting with development needs (Abedian \& Standish, 1992).

In the 1950s and 1960s South Africa enjoyed good economic growth: the economy was dynamic with annual growth rates in excess of 5\% (Brixen \& Tarp, 1996). The end of the 1960s marked the highpoint of South Africa's economic growth in the second half of this century. Economic growth has declined almost consistently since then. In the 1970s, despite increased gold prices, the economy grew at an annual rate of only $2.5 \%$. Three factors were seen to be the cause of this. These were (1) the pressures for change in the country (both internally and externally) leading to declining confidence by both foreign and domestic investors, (2) import substitution policy reaching its limits and export promotion not being pursued, a slowdown in industrialisation and manufacturing's increased dependence on what happened in the gold market and (3) the poor conduct of monetary and exchange rate policies, leading to inflation and further reducing investments. In the 1980s South Africa's average annual growth rate was at $1.1 \%$, although in some years it was actually negative. Numerous factors were attributed to this downturn, including the strikes of 1973 and the Soweto uprising of 1976. This resulted in raised relative labour prices, which then decreased returns on investments, causing investments to decline as well. Part of the economic crisis the country experienced during that period was blamed on the unfavourable political developments, including the disinvestment campaign, sanctions and boycotts. Foreign capital was compromised and became a net capital outflow (Abedian \& Standish, 1992).

In the first decade after 1994, South Africa's economic growth was impressive, rising from $3 \%$ to about $5 \%$ in 2006 . The growth has been attributed to high commodity prices, large capital inflows, strong domestic consumer demand and rising asset prices, among other things.

\section{SELECTED LITERATURE REVIEW}

The conventional idea has been that increased savings leads to increased growth. The underlying assumption in most of these studies is that increased savings ensures there is more funds for investment. It is this increase in investment that will then drive the growth of the economy. Proponents of this school of thought include Lewis (1954), Lean and Song (2009) and Sheggu (2009), who found a positive long-run relationship between growth in savings and economic growth. Bacha (1990), DeGregorio (1992), and Jappelli and Pagano (1994) found that in the short run savings contributed to growth through increased investment channels. Aghion et al. (2009) found that savings contributes to growth in places where companies and entrepreneurs lacked technological advances, and the only way to overcome that was for them to use savings as collateral with which to attract investors.

Savings and economic growth studies examining the direction of causality yield differing results. Mohan (2006) examined the relationship between savings and economic growth for high-, middle- and low-income countries utilising annual data from 1960 to 2001. Contrary to the traditional view, the results indicated that casualty ran from economic growth to savings. The findings also indicate that in countries with a forced savings policy like Singapore, causality runs from savings to economic growth. Similar results are observed by Sheggu (2009), who modelled the relationship between savings and economic growth in Ethiopia from 1960 to 2003 in a vector autoregressive model (VAR) model. Sheggu found that faster growth rates in the gross 
domestic savings caused higher growth rates in real GDP in Ethiopia. Conversely, Salz (1999) used Granger causality in an error correction framework to investigate the causal relationship between savings and growth in third world countries and found that higher growth leads to faster growth in the savings rate. The result suggests that in addition to promoting higher savings, policies promoting economic growth are also essential.

Lean and Song (2009) examined the domestic savings and economic growth relationship for China from 1955 to 2004, employing cointegration and causality tests. China has enjoyed high levels of economic growth and savings for a number of decades and they found that, indeed, there was a long-run relationship between economic growth and savings in China, taking into account the two savings rates they employed: household savings and enterprise savings. They found the existence of bilateral causality between domestic savings and economic growth in the short run and unidirectional causality from domestic savings growth to economic growth in the long run.

Aghion et al. (2009) examined whether domestic savings matters for economic growth. Their model focused on the idea that growth is a corollary of technological innovations and therefore in the case of poor countries that are constantly playing catch-up with new technology, they require foreign investors to work together with domestic entrepreneurs who know the workings of the domestic economy. Therefore domestic savings is essential for innovation and growth. This however does not apply to developed or rich nations that already have the technological knowhow. They also argued that given the fact that investments can be financed by foreign savings, domestic savings is not important for the growth process. Their study found that domestic savings is more important for adopting new technologies in developing (poor) rather than developed (rich) nations.

A number of studies have examined the relationship between savings and economic growth in South Africa. Tsikata (1998) highlighted the importance of public savings for the South African economy and observed that declines in public savings result in an overall decline in aggregate savings. The finding implies that policies to address public savings are important. Aron and Muellbauer (2000) examined the role played by financial liberalisation in savings behaviour in South Africa and concluded that financial liberalisation impacts on private savings negatively. Gunnar and Teferra (2001) examined the relationship between savings and economic growth through the financial liberalisation channel and found that in South Africa savings is encouraged by policies that control the level of personal borrowing, while financial liberalisation reduces household savings. Using a vector error correction model (VECM) approach, Romm (2003) examined the relationship between savings and growth in South Africa from 1946 to 1992. The results point to an indirect effect of private savings growth through the effect of private savings on investment. The paper found that savings enhanced growth and at the same time growth enhanced savings.

\section{MODEL SPECIFICATION AND DATA}

This study uses annual time series covering the period 1953-2008. A multivariate approach to investigate the relationship between household, corporate savings and economic growth is used. The variables considered are real gross domestic product (GDP) as a proxy for economic growth measured in millions of Rand, and household, government and corporate savings measured in 
millions of Rand. The data on these variables was sourced from the South African Reserve Bank database.

In the empirical studies examining the relationship between savings and economic growth, a common feature is the use of a bilateral causality approach (Mohan, 2006), and in some cases a multilateral causality approach (0dhiambo, 2009). Another commonality between these studies is the use of aggregate savings (0dhiambo, 2009; Romm, 2003). Using a multivariate approach, gross domestic product is specified as a function of household savings, corporate savings and government savings. Where this method is different is in the inclusion of the different types of savings within the economy. The model takes the following form:

$$
Y_{t}=a_{0}+a_{1} H S_{t}+a_{2} C S_{t}+a_{3} G S_{t}+\varepsilon_{t}
$$

where $y_{t}$ is gross domestic product, HS is household savings, CS is corporate savings and GS is government savings. It is expected that corporate savings will positively impact on growth and, given the nature of household and government savings, the impact on growth is expected to be positive or negative. Negative values in both the household and government series prevent the use of natural logs.

\subsection{Autoregressive Distributed Lag (ARDL)}

This study employs the ARDL bounds-testing approach to cointegration developed by Pesaran and Shin (1999) and later extended by Pesaran et al. (2001). The ARDL bounds-testing approach to cointegration has gained significance in econometric analysis in recent years because of the advantages it provides over techniques such as the Johansen-Juselius (JJ) cointegration and the dynamic ordinary least squares (DOLS) technique. Firstly, compared to the Johansson approach to cointegration, ARDL removes the restrictions found in traditional cointegration estimation approaches. It allows cointegration analysis to be undertaken irrespective of the order of integration of the underlying regressors - i.e. whether the regressors are integrated of zero order $[I(0)]$, order one $[I(1)]$. The use of the ARDL bounds test is therefore deemed suitable where the stationarity of a variable is called into question. Secondly, as suggested by Houge and Yosup (2010), since the issue of sample size is removed in the ARDL approach, this makes it appropriate for analysing cointegration in small samples. Thirdly, when the model includes regressors that are endogenous, the bounds-testing approach provides unbiased long-run estimates and valid t-statistics (0dhiambo, 2008). Lastly, where the variables are cointegrated, the single equation ARDL estimator gives highly consistent estimates of the long-run parameters and valid t-ratios, even in the presence of endogenous explanatory variables (Inder, 1993; 68). In addition, the J cointegration method is more efficient in multivariate systems, and the DOLS approach requires that the series in the model be non-stationary (Amusa \& Moyo, 2013).

Equation $\mathrm{l}$ is thus modelled as a conditional autoregressive distributed lag (ARDL) in a generic form as follows: 


$$
\begin{aligned}
\Delta G D P_{t}=\emptyset_{0}+ & \sum_{i-1}^{m} \emptyset_{1 i} \Delta G D P_{t-i}+\sum_{j=0}^{n} \emptyset_{2 j} \Delta H S_{t-j}+\sum_{k=0}^{p} \emptyset_{3 k} \Delta C S_{t-k} \\
& +\sum_{l=0}^{r} \emptyset_{4 l} \Delta G S_{t-l}+\varphi_{1} G D P_{t-1}+\varphi_{2} H S_{t-1}+\varphi_{3} C S_{t-1} \\
& +\varphi_{4} G S_{t-1}+\varepsilon_{t}
\end{aligned}
$$

From equation (2) the parameters $\emptyset_{i}$ capture the coefficients of the short run dynamic, $\varphi_{1} \varphi_{2} \varphi_{3}$ and $\varphi_{4}$ are the long run-multipliers, while $\Delta$ denotes the first difference operator t-1 denotes one-period lag, $\sum_{i=1}^{m}$ denotes the sum of $\mathrm{i}=1,2,3, \ldots \mathrm{m} ; \sum_{j=0}^{n}$ denotes the sum of $j=$ $0,1,2, \ldots n$.

The bounds test approach requires examining the null hypothesis of an absent conditional or 'no conditional' relationship using a joint significance test, the F-test, of the lagged levels of the variables. Taking GDP as the dependent variable, the null hypothesis of no cointegration is $\mathrm{H}_{0}: \psi_{1}=\psi_{2}=\psi_{3}=\psi_{4}=0$ against the alternative hypothesis $\left(\mathrm{H}_{1}: \psi_{1} \neq \psi_{2} \neq \psi_{3} \neq \psi_{4} \neq\right.$ 0 ). This is denoted by $\mathrm{F}_{\mathrm{GDP}}$ (GDP /CS, GS, HS). The null and alternative hypotheses are evaluated on the basis of estimated standard F-statistic. Narayan (2005) computes the critical values for small samples ranging from 30-80 observations, which is applicable to this study. The critical value bounds hold for all classifications of regressors that are into purely I(1), purely I(0) or mutually cointegrated (Narayan \& Smyth, 2005).

Determination of cointegration rests on the F-statistics and the upper and lower bounds. If the computed F-statistic falls outside the upper bound, the null hypothesis of no cointegration is rejected. If the computed F-statistics falls below the lower bound, the conclusion that the null hypothesis cannot be rejected is reached and if the computed F-statistics falls within the critical value band, the result of inference is inconclusive.

To obtain the long-run effects, the coefficient of one period lagged independent variable is divided by the coefficient of the one period lagged dependent variable and the value obtained is multiplied by a negative sign. That is, the long-run coefficient is given by $-\left(\frac{\psi_{2}}{\psi_{1}}\right)$ The short-run effects are the coefficient of the first order differenced variables.

\section{EMPIRICAL RESULTS}

\subsection{Unit root tests}

An advantage of the ARDL approach is the lack of restrictions it places on variables being integrated of order zero I $(0)$, order one I(l) or cointegrated. However, the method requires that the variables not be $I(2)$. Cognisance is taken of this necessary requirement and both the Dickey-Fuller 2GLS and the Phillips-Peron tests are performed, with the optimal lag length determined by the Schwartz Information Criterion (SIC). The tests are carried out at levels and on first differences using intercept and intercept plus trend (TABLE 1 ). Using the Phillips-Perron 
and Dickey-Fuller 2GLS tests, the results in TABLE 1 indicate that the variables are integrated of order one.

TABLE 1: Summary of Unit Root Results

\begin{tabular}{|c|c|c|c|c|}
\hline \multirow[t]{3}{*}{ Variables } & \multicolumn{4}{|c|}{ Phillips-Perron } \\
\hline & \multicolumn{2}{|c|}{ Levels } & \multicolumn{2}{|c|}{ First difference } \\
\hline & Intercept & Trend \& Intercept & Intercept & Trend \& Intercept \\
\hline GDP & -2.13 & 0.63 & $-3.64 \star \star \star$ & $-4.09 \star \star$ \\
\hline HS & -1.38 & -0.66 & $-6.02 * \star \star x$ & $-6.31 * \star \star$ \\
\hline GS & -2.44 & -2.59 & $-5.80 \star \star \star$ & 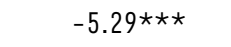 \\
\hline \multirow[t]{2}{*}{ CS } & -0.34 & -2.79 & $-6.10 \star \star \star$ & 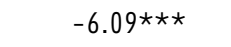 \\
\hline & \multicolumn{4}{|c|}{ DF-GLS } \\
\hline \multirow[t]{2}{*}{ Variables } & \multicolumn{2}{|c|}{ Levels } & \multicolumn{2}{|c|}{ First difference } \\
\hline & Intercept & Trend \& Intercept & Intercept & Trend \& Intercept \\
\hline GDP & 1.69 & -1.32 & 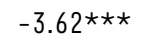 & 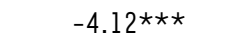 \\
\hline HS & -1.29 & -1.15 & $-6.61 \star \star \star$ & $-6.93 \star \star \star$ \\
\hline GS & -2.34 & -2.67 & $-6.00 \star \star \star$ & $-5.17 \star \star \star$ \\
\hline CS & -2.65 & -2.80 & $-6.51 * \star \star$ & $-5.58 * \star \star$ \\
\hline
\end{tabular}

Source: Authors estimations based on SARB data

Indicates significance at the $\star \star \star 1 \%, \star \star 5 \%$; (ii) Critical values for PP at levels for PP statistic (with intercept) at $1 \%, 5 \%$ and $10 \%$ are $-3.55,-2.91,-2.59$ respectively; (iii) Critical values for PP at levels for PP statistic (with intercept and trend) at $1 \%, 5 \%$ and $10 \%$ are $-4.13,-3.49,-3.17$ respectively; (iv) Critical values for DF-GLS at levels (with intercept) at $1 \%, 5 \%$ and $10 \%$ are $-2.90,-1.94,-1.61$ respectively; (v) Critical values for DF-GLS at levels (with intercept and trend) at $1 \%, 5 \%$ and $10 \%$ are $-3.75,-3.17,-2.87$ respectively

To examine the impact of impact of household, corporate and government savings on GDP, an ARDL model with three lags of equation 1 is estimated. The general to specific modelling approach is followed and the Akaike information criterion (AIC) is used to guide the selection of the parsimonious model. The estimated model outlined here is based on minimising the AIC information criterion. A general model of ARDL was first performed with the lag length of three for the differenced variables as selected by the entire lag length criteria. The insignificant variables were then gradually dropped, observing the Akaike information criterion in order to note the importance of the variables being dropped. The results are presented in TABLE 2. 
TABLE 2: Estimated ARDL model of equation 1

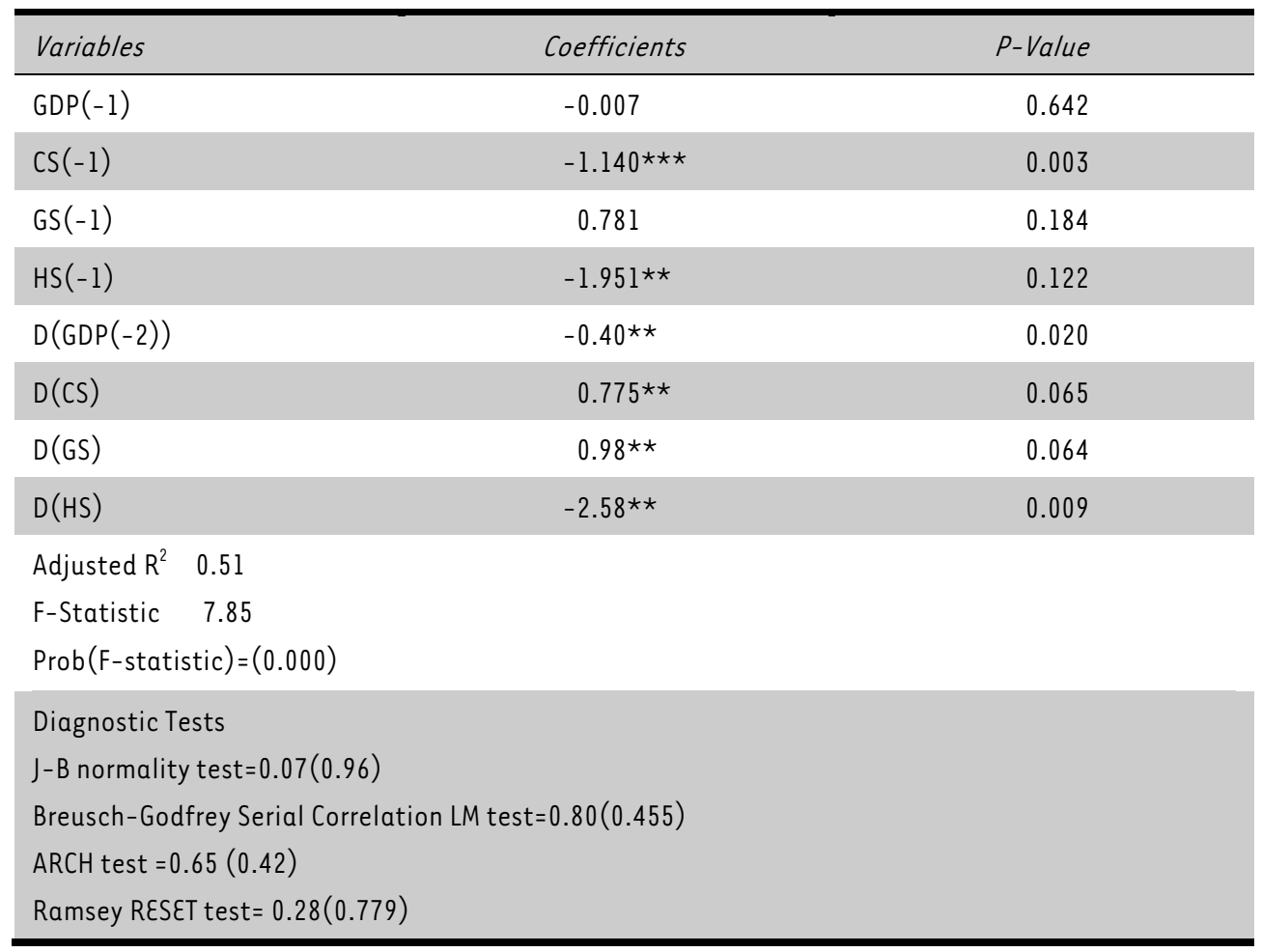

Source: Estimations based on SARB data

Notes: $* \star \star \star \star \star$ represent significance at $10 \%, 5 \%$ and $1 \%$ level of significance.

In order to establish the soundness of the equation estimated, a number of diagnostic tests, including the Jarque-Bera normality test, the Breusch-Godfrey serial correlation LM test, the Ramsey reset for model specification and ARCH test for heteroskedasticity, are carried out. The reported statistic of the Jarque-Bera test for normality rejects the null hypothesis that the estimated residual series are not normally distributed. Second-order serial correlation is rejected, as indicated by the LM statistic of $0.80(0.455)$. The conclusion is therefore reached that the model does not suffer from serial correlation. The ARCH test for heteroskedasticity shows that the residuals do not suffer from heteroskedasticity, while the Ramsey Reset test confirms the use of the correct functional form of the savings equation.

\subsection{Cointegration test results}

In order to establish the existence of a long-run relationship between the variables, the bounds test is performed. The calculated $F$-statistics, together with the critical values, are reported in TABLE 3. The calculated F-statistic $F_{G D P}(G D P / C S, G S, H S)=4.70$ is greater than the upper bound of the critical value of 3.792 at the $5 \%$ level of significance (and 3.273 at the $10 \%$ level). 
TABLE 3: Cointegration test results

\begin{tabular}{|c|c|c|c|c|c|c|}
\hline \multicolumn{7}{|c|}{ Critical value bounds of the F statistics: restricted intercept and no trend } \\
\hline \multirow{4}{*}{$\begin{array}{l}\text { F-statistics } \\
(k=4, T=56)\end{array}$} & \multicolumn{6}{|c|}{ Critical Values } \\
\hline & \multicolumn{2}{|c|}{$1 \%$ level } & \multicolumn{2}{|c|}{$5 \%$ level } & \multicolumn{2}{|c|}{$10 \%$ level } \\
\hline & $I(0)$ & $\mathrm{I}(1)$ & $I(0)$ & $\mathrm{I}(1)$ & $I(0)$ & I(1) \\
\hline & 3.710 & 4.965 & 2.743 & 3.792 & 2.323 & 3.273 \\
\hline \multicolumn{7}{|c|}{$\mathrm{FGDP}=(\mathrm{GDP} \backslash \mathrm{HS}, \mathrm{GS}, \mathrm{CS})=4.70 * \star$} \\
\hline
\end{tabular}

Source: Estimations based on SARB data

Critical values obtained from Narayan (2005), Case II, p.1987. I(0) - lower bound; I(1) - upper bound. * $10 \%$; $\star \star 5 \% ; * \star \star 1 \%$.

The result shows that that the null of no cointegration among the variables is rejected. The coefficients $\psi_{k}$ are significantly different from zero. The critical values obtained from Narayan (2005) show that the calculated F-statistic exceeds the upper critical limit at $10 \%$ and $5 \%$ levels. This therefore implies that there is a long-run relationship among these variables.

\subsection{Long- and short-run effects}

The bounds test provides evidence of a cointegration relationship between GDP, CS, GS and HS when GDP is taken as the dependent variable. To obtain the long-run effects, the coefficient of one period lagged independent variable is divided by the coefficient of the one period lagged dependent variable and the value obtained is multiplied by a negative sign. The short-run elasticities are the coefficient of the first-order differenced variables. The estimated short-and long-run effects of the different forms of savings are reported in TABLE 4.

TABLE 4: Short-run and long-run relationships

$$
\text { PANELA }
$$

\begin{tabular}{|c|c|c|c|}
\hline Variables & Short-Run & Long-Run & \\
\hline HS & $-2.59 \star \star \star$ & -259 & \\
\hline GS & $0.98 * \star \star$ & 107.7 & \\
\hline CS & $0.78 * \star \star$ & $151.58 * \star \star$ & \\
\hline \multicolumn{4}{|c|}{ Panel B: Diagnostic tests of the ARDL model (figures in parentheses indicate P-value) } \\
\hline Jarque-Bera & & JB: & $0.078(0.961)$ \\
\hline Serial Correlation LM Test ${ }^{+}$ & & F-statistic: & $0.800(0.456)$ \\
\hline Heteroskedasticity Test ${ }^{++}$ & & F-statistic: & $0.767(0.633)$ \\
\hline Ramsey RESET Test & & F-statistic: & $0.578(0.56)$ \\
\hline
\end{tabular}

Source: Estimations based on SARB data

$\star 10 \% ; * \star \star 1 \%$. Breusch-Godfrey. Breusch-Pagan-Godfrey. 


\subsection{Discussion of results}

An important finding of the study is that, in the short run, government, corporate and household savings significantly impact on growth, although government savings and corporate savings positively affect growth while household savings impact negatively on growth. The results show that in the long run, only corporate savings has a significant positive impact on growth. Government and household savings has no significant impact on growth in the long run. The results from the empirical analysis of the savings and growth relationship in South Africa show the importance of savings for the country's growth. The fact that corporate savings have more of a positive impact on growth than household savings is not surprising especially given the minimal contribution of household savings to overall national savings, as reflected by the savings GDP ratio over the last three decades. The positive and significant relationship between corporate savings and economic growth in both the short- and long-run periods is further supported by other studies carried out on the South African economy (Romm, 2003; Odhiambo, 2009) and studies on other developing economies (Sheggu, 2009; Mohan, 2006).

The insignificant relationship in the long run between household savings, government savings and growth allows one to conclude that it is important that South Africa develops and implements policies and schemes that allow for increased savings, especially on the household level. This will help to improve overall national savings and further boost economic growth. Household savings in South Africa are strongly highly influenced negatively by government policies in place. Strydom (2007) highlights the large disparity between corporate and household taxes, which induces households to channel their incomes to corporates instead of save. The savings trend of households in South Africa is therefore geared away from discretionary savings and towards financial assets. There is therefore a need to address the policies that impact on the savings behaviour of households in South Africa in the form of a strong financial sector that provides numerous profitable and efficient financial instruments that will encourage households to save. South Africa can stand to learn from the countries that have implemented mandatory savings policy - for example Singapore, which has been successful at boosting savings through such programmes. Continued effort at increasing government savings is also important in overhauling the declining savings trend. Improved efficiency in governments tax efforts, reduced service delivery and declines in the budget-GDP ratio have been attributed to the upsurge in government savings (Strydom, 2007). In 2006, for the first time government savings moved into positive territory.

\section{SUMMARY AND CONCLUSIONS}

The impact of savings on economic growth has been widely examined for both developed and developing economies with differing results based on the methodology adopted, time period under consideration and country studied. A significant number of empirical studies on the savings and growth nexus, including those that examine the issue for South Africa, have focused for the most part on aggregate savings. The aim of this study is to re-examine the relationship between savings and economic growth in South Africa with a focus on establishing the long and short run impact of disaggregated savings in South Africa on economic growth. As a departure from other savings and growths studies that use South Africa as a case study, the effects on growth of corporate, household and government savings is examined. Observations of the domestic savings trend in the country highlights the consistently low savings rates in both the 
household and government sectors, while the corporate sector is seen to be the largest contributor to domestic savings. Using bounds test approach to cointegration within an ARDL framework, the empirical analysis highlights the importance of savings for growth in the South African economy. Furthermore, disaggregating national savings into corporate, household and government savings allows for the determination of the significance and impact of each type of savings on growth. Not surprisingly, corporate savings (the highest contributor to national savings) has a positive impact on growth in both the short and long run. On the other hand, given that household savings account for only a small share of national savings, the insignificant impact on growth is not surprising. Based on the revealed importance of domestic savings in boosting growth, policies that will address the low household savings rates evident in the South African economy need to be implemented.

\section{LIST OF REFERENCES}

Abedian, R., \& Standish, B. (1992). Economic growth in South Africa: Selected policy issues, Cape Town: Oxford University Press.

Aghion, P., Comin, D., Howitt, P., \& Tecu, I. (2009). When does domestic saving matter for growth? National Bureau of Economic Research. Working Paper 12275.

Amusa, K. \& Moyo, B. (2013). Savings and economic growth in Botswana: An analysis using bounds testing approach to cointegration. Journal of Economics and Behavioural Studies, 5(4), pp.200-209.

Aron, J., \& Muellbauer, J. (2000). Personal and corporate saving in South Africa. The World Bank Economic Review, 14 (3), pp. 509-544.

Bacha, E.L. (1990), A three-gap model of foreign transfers and the GDP growth rate in developing countries, Journal of Development Economics, 32(2), pp.279-296.

Brixen, P. \& Tarp, F. (1996). South Africa: Macroeconomic perspectives for the medium term. World Development, 24(6), pp. 989-1001.

DeGregorio, J. (1992). Economic growth in Latin America, Journal of Development Economics, 39, pp. 59-84.

Gunnar, J. \& Teferra, H. (2001). Pattern and determination of private saving in South Africa. Washington: International Monetary Fund.

Hoque, M.M. \& Yusop, Z. (2010). Impacts of trade liberalisation on aggregate import in Bangladesh: An ARDL bounds test approach. Journal of Asian Economics, 21(1), pp. 37-52.

Inder, B. (1993). Estimating long-run relationships in economics: A Comparison of Different Approaches. Journal of Econometrics, 57(1), pp. 53-68.

Japelli, T. \& Pagano, M. (1994). Savings, growth and liquidity constraints, Quarterly Journal of Economics, 109(1), pp. 83-109.

Kerr, R. (1997). An economic analysis of compulsory savings. Presented at New Zealand business roundtable, May 1997.

Lean, H, H. \& Song, Y. (2009). The domestic savings and economic growth relationship in china. Journal of Chinese Economic and Foreign Trade Studies, 2(1), pp. 5-17. 
McKinnon, R.I. (1973). Money and capital in economic development, Washington DC: Brookings Institution

Mohan, R. (2006). Causal relationship between savings and economic growth in countries with different income levels. Economics Bulletin, 5(3), pp. 1-12.

Narayan, P.K. (2005). The saving and investment nexus for China: Evidence from cointegration test. Applied Economics, 37(17), pp. 1979-1990.

Odhiambo, N.M. (2008). Financial depth, savings and economic growth in Kenya: A dynamic causal linkage. Economic Modeling, 25(4), pp. 704-713.

Odhiambo, N.M. (2009). Savings and economic growth in South Africa: a multivariate causality test. Journal of Policy Modeling, 31(5), pp. 708-718.

Pesaran, M. \& Shin, Y. (1999). An autoregressive distributed lag modeling approach to cointegration analysis. In Strom, S. ( $\varepsilon d)$, Econometrics and Economic Theory in the $20^{\text {th }}$ Century: The Ragner Frisch centennial Symposium. Cambridge University Press; Cambridge.

Pesaran, M. H., Shin, Y., \& Smith, R. J. (2001). Bound testing approaches to the analysis of level relationships. Journal of Applied Econometrics, 16(3), pp. 289-326.

Prinsloo, J. W. (2000). The saving behavior of the South African economy. Occasional paper No 14, South African Reserve Bank.

Romm, A.T. (2003). The relationship between savings and growth in South Africa: an empirical study. University of Witwatersrand. [Online] Available: http://www.tips.org.za/files/688.pdf. (2012).

Salz, I.S. (1999). An examination of the causal relationship between savings and growth in the third world. Journal of Economics and Finance, 23(1), pp. 90-98.

Shaw, E.S. (1973). Financial deepening in economic development. New York: Oxford University Press. [Online] Available: http://ideas.repec.org/a/eee/wdevel/v2yl974i10-12p76-77.html. (2012).

Sheggu, D. (2009). Causal relationship between growth and real gross domestic savings: evidence from Ethiopia. Ethiopian Economic Association, second international Conference on the Ethiopian Economy, June 3-5, United Nations Conference Center (UNCC), Addis Ababa.

Strydom, P. (2007). Saving behavior by South African Households. First National Bank. [Online] Available: https://www.fnb.co.za/economics/econhtml/docs/SavingHouseholds.pdf. (2011).

Solow, R.M. (1956). A Contribution to the theory of economic growth. Quarterly Journal of Economics, 70, pp. 65-94.

South African Reserve Bank (SARB) Annual report, various years.

South African Reserve Bank Online Database. [Online] www.resbank.co.za.

Tsikata, Y. (1998). Saving in South Africa: An Empirical Investigation. Washington: World Bank. 
Amusa 